\title{
Fiscal Imbalances and Interest Rate Change in Pakistan: A Co-Integration Analysis
}

\author{
Zaeema Islam', Asghar Ali², Irfan Ahmad Baig3, Sajjad Ahmad Baig4, \\ Muhammad Hashim ${ }^{4}$, Muhammad Zia-Ur-Rehman ${ }^{4}$ \\ ${ }^{1}$ M.Sc (Hons) Development Economics, Institute of Agricultural and Resource Economics, University of Agricul- \\ ture Faisalabad, Faisalabad, Pakistan \\ ${ }^{2}$ Institute of Agricultural and Resource Economics, University of Agriculture Faisalabad, Faisalabad, Pakistan \\ ${ }^{3}$ Department of Economics \& Agricultural Economics, PMAS-Arid Agriculture University, Rawalpindi, Pakistan \\ ${ }^{4}$ Department of Business Administration, National Textile University, Faisalabad, Pakistan \\ Email: sajiy2k@hotmail.com
}

Received 11 May 2015; accepted 6 October 2015; published 9 October 2015

Copyright (C) 2015 by authors and Scientific Research Publishing Inc.

This work is licensed under the Creative Commons Attribution International License (CC BY).

http://creativecommons.org/licenses/by/4.0/

(c) (i) Open Access

\begin{abstract}
The study investigated the relationship among fiscal deficit, public debt, inflation, international interest rates and the interest rate change in Pakistan using time series data for the period 1981-2011. Augmented Dickey Fuller Unit root test was used to check stationarity of time series data. The study employed co-integration approach to check the long-run relationship among variables. The findings of the study showed a positive and significant relationship between explanatory variables and interest rate change. The study suggested that the fiscal deficit, public debt and double digit inflation should be controlled in order to decrease the interest rate and interest rate fluctuation in Pakistan.
\end{abstract}

\section{Keywords}

Interest Rate, Co-Integration, Pakistan

\section{Introduction}

The role of financial sector is mainly depending upon the macroeconomic variables. The stabilization of the important macroeconomic variables causes the economy to grow. Financial sector mainly focuses on the money supply which is the main ingredient in the monetary policy formulation. However, looking at world's new pattern of the monetary aggregates, policy makers are more interested in nominal interest rate targeting than altering the money supply nowadays. The reason behind this change in money targeting to interest rate targeting is 
the unpredictable and unsustainable demand function of money.

The monetary policy transmission is very crucial in understanding the monetary pillars of any economy. The determinants of interest rate predict the monetary policy framework and tell that how it will act in future with the macroeconomic conditions, financial market structure and the developmental mechanism. Among the different sources of monetary policy transmission, the interest rate is the basic and traditional mechanism. With the growing rate of inflation, the interest rate mechanism has more commonly used in the monetary policy transmission (Gigineishvili, 2011) [1].

Pakistan has been facing a chronic fiscal deficit due to poor management and harsh spending behavior for the last two decades. To finance the deficit through different fiscal and monetary measures including bank borrowing, printing of money caused inflation and led to the higher debts. Interest payments on domestic debt increased and added to the fiscal imbalance. The measures to bridge the fiscal deficit can also create crowding out effect which again results in large interest rates. If the interest rate to GDP ratio is large enough then all financial markets will frighten because they may be attracted towards default or their real value of debt money will be lower down by the debt-ridden government due to high inflation. Hence they demand higher rate of interests from indebted government and make the fiscal distresses more alarming (Bonga-Bonga, 2011) [2].

The increasing debt causes inflation to rise and in turn domestic rate of interest. The proper debt servicing strategy is adopted by the legislators to limit the debt within the annual budget. The careless consumption expenditures on government level like lavish living styles, foreign tours, extravagant expenses on protocols causes borrowing from internal as well as external sources. The inflation is considered as a major cause in broadening the debt borrowing, rise in nominal interest rate and the depreciation of money. The begging bowl should be thrown and efforts should be made to portray the actual image of Pakistan. The donors can then be attracted; hence they will pay the grants and write off all the big debts (ADB, 2004) [3].

The debates about the association among the fiscal deficits, debt burden and inflation to the interest rate change provoked for this research. Huge fiscal deficits have a negative effect on the economy as it reduces the national savings, which in turn has off-putting effect on the domestic investment and thus cause a rise in borrowing. The escalating public debt and fiscal deficit is not advanced for the macroeconomic strength and augmentation because it exerts upward pressure on the interest rate and hence crowds out domestic private investment. The high interest rate is linked with large fiscal deficits, heavy domestic debt load thus exerting pressure on budgetary resources, with a depressing effect on the development and growth. So it is important to analyze the relationship and check the trend with which the interest rate moves with growing fiscal deficits, government debt and high rate of inflation (ADB, 2004) [3]. The basic objective of the present research was to investigate the impact of fiscal deficit, inflation rate and public debt on interest rate change and then to give policy recommendations and suggestions.

The paper is structured as follows: part II reviews the literature on the relationship among interest rate, fiscal deficit, inflation and public debt. Methodology for assessing the determinants of interest rate change is discussed in part III. Part IV discusses the results of the empirical analysis, and the conclusion and policy recommended are presented in the last part of the paper.

\section{Review of the Literature}

This part reviewed the relevant studies on the association among fiscal imbalance, public indebtness, rate of inflation and interest rates. Numerous studies have revealed that gigantic deficits, high prices and public debts raise the interest rates in positive manner.

Many researchers had studied the relation of interest rate to inflation, fiscal deficit and the public debt among them are Cohen and Garnier (1991) [4]; Canzoneri et al. (2002) [5]; Laubach (2003) [6]; Gale and Orszag (2003) [7]; Bashir (2004) [8]; Dai and Phollipon (2004) [9]; Kameda (2008) [10] and Bonga-Bonga (2011) [2]. All these studies showed a positive and significant relationship of fiscal deficit to the interest rate change.

Bashir (2004) [8] studied the reasons of large fiscal imbalance in a report form. The study was based on the fiscal deficit gap of Pakistan and provided a logical reasoning of huge debt burden. The analysis argued that debt burden was mainly due to deficits. The research also concluded that deficits were financed through two ways either internal sources or external sources.

Engen and Hubbard (2004) [11]; Shapiro (2004) [12]; Gosselin and Lalonde (2005) [13] and Marattin and Salotti (2010) determined a positive relationship in different ways. Utami and Inanga (2009) [14] and Brzezina 
(2002) [15] studied the relationship of inflation and interest rate and depicted that the inflation was a significant ingredient that caused interest rate to change. Obi and Nurudeen (2009) [16] showed the effect of fiscal deficit and government debt along with inflation on nominal interest rate and examined a positive significant relationship among these variables.

Hall and Sargent (2010) [17] studied the interest rate risks and other determinants. They determined the U.S debt to GDP ratio of post World War-II. The results showed that 15.8 percent increase in debt in marketable and non-marketable was due to inflation rate, 31.8 percent because of real GDP and 34.7 percent due to primary surpluses. Gigineishvili (2011) [1]; Adjei et al. (2012) [18] examined the long-run interest rate determinants and showed the positive significant increase in interest rate.

Gigineishvili (2011) [1] identified the determinants of interest rate pass through and its determinants. The study used the cross sectional data for the period of 2006 to 2009 from seventy countries included developed, developing and underdeveloped. Moreover, in the advanced countries where the GDP per capita was large, the interest rate passes through was also found to be stronger one.

Haq and Aurangzeb (2012) [19] examined the determinants of inflation in Pakistan. The gross domestic product (GDP) showed negative impact on inflation while all the other variables had positive relationship with inflation rate. Another study was conducted by Rais and Anwar during 2012. They studied the impact of public debt on the economic growth and development in Pakistan and gave the reasons to public debt enlargement that in turn caused the interest rate change.

\section{Methodology}

Following model was used in present study to analyze the impact of different variables on interest rate change. Obi and Nurudeen (2009) [16] had also used the interest rate as dependent variable.

$$
\text { LINT }=f(\text { LFDFCT, LGOVD, LINFL, LUSINT, } e)
$$

It is clearly described in the review of literature that these variables are also used in many studies but these studies show the separate impact on the interest rate change. Monetary aggregates can also be used in the equation but this is the other side of the coin.

\subsection{Data and Variables}

\subsubsection{Sources of Data}

To probe the association, annual time series data were collected from Economic Survey of Pakistan and different publications of State bank of Pakistan for the period of 1981 to 2011.

\subsubsection{Description of Variables}

This section looks at the expected signs of the variables shown in Equation (1).

\section{1) Interest Rate (INT)}

Interest rate is used as a dependent variable and proxied by weighted average rate of return on deposits ${ }^{1}$. A positive relation of interest rate change with inflation, fiscal deficit and public debt can be expected.

\section{2) Overall Fiscal Deficit (FDFCT)}

This variable is used as an independent variable. The overall fiscal deficit is used as percentage of GDP. The expected result of fiscal deficit is positively related to interest rate change.

\section{3) Public Debt (GOVD)}

The important explanatory variable is the public debt. The Government Debt to GDP ratio is used and the total government debt is divided by GDP annual growth rate. The GOVD is associated positively with interest rate. Many researchers used these variables separately and they impact directly on the interest rate change. These both are the current macroeconomic problems which Pakistan is suffering from the last decade and the study used both of the variables to study the combined effect in the presence of inflation which were not studied before.

\section{4) Rate of Inflation (INFL)}

The GDP deflator is used as a proxy for rate of inflation. Inflation rate can be expected to be positively associated with interest rate change.

\footnotetext{
${ }^{1}$ Weighted average rate of return on deposits $=\sum($ rate $*$ amount $) / \sum($ amount $)$
} 


\section{5) International Interest Rate (USINT)}

The International interest rate is also used as an independent variable and is proxied by the United States interest rate.

\subsection{Analytical Framework}

\subsubsection{Unit Root Test}

Dickey Fuller test can be applied in three different forms along with three different types of null hypothesis.

1) $X_{t}$ is random walk:

$$
\Delta X_{t}=\partial X_{t-1}+\mu_{t}
$$

2) $X_{t}$ is a random walk with drift:

$$
\Delta X_{t}=\alpha_{0}+\partial X_{t-1}+\mu_{t}
$$

3) $X_{t}$ is a random walk with drift and a trend:

$$
\Delta X_{t}=\alpha_{0}+\alpha_{1} t+\partial X_{t-1}+\mu_{t}
$$

First model does not involve an intercept term and trend, hence categorized as Random Walk Model (RWM) without drift and trend. Second model includes an intercept term but no trend, called as RWM with drift. However, third model includes both intercept term and trend, called as RWM with drift and trend. If trend of time series data is completely forecasted, then it is deterministic trend otherwise stochastic trend. Each form has its own critical value depending upon the sample size. Anyhow, in each case null hypothesis is $\partial=0$, represents the presence of unit root and series is non-stationary (Dickey et al., 1986 [20]).

$$
\Delta X_{t}=\alpha_{0}+\alpha_{1} t+\partial_{1} X_{t-1}+\cdots+\partial_{k} X_{t-k}+\mu_{t}
$$

Here $\alpha_{0}$ is intercept term, and $\alpha_{1}$ is coefficient of time trend. In this model if the restriction $\alpha_{0}=0$ and $\alpha_{1}=0$ enforce, this becomes random walk model without drift and if applied the restriction $\alpha_{1}=0$, this converted the model random walk with the drift. Dickey Fuller and Augmented Dickey Fuller test assumes that there is only one unit in the processes (Dickey et al., 1986 [20]).

\subsubsection{Testing for Co-Integration}

The basic purpose of co-integration is to determine the long-run relationship between variables. Co-integration test using Johnsen’s methodology starts from vector auto regression (VAR) of order $k$, given as under:

$$
\Delta X_{t}=\alpha_{0}+\partial_{1} X_{t-1}+\cdots+\partial_{k} X_{t-k}+\mu_{t}
$$

Here $X_{t}$ is an $(n \times 1)$ vector of variables that are integrated of order one i.e. I(1) (Hjalmarsson and Osterholm, 2007 [21]). Variables, which are co-integrated, fulfilled two conditions. First, at least two of individual variables series have the same order and second, integrated variables exhibit linear combination to an order, which is lower than the individual variables (Hansen and Juselius, 1995).

Johansen's full Information Maximum Likelihood (FIML) approach persuades to eliminate all possible cointegrating vectors and how they work in the system (Johansen and Juselius, 1990 [22]). If all the series involved in the analysis would be co-integrated of the same order, then Johansen's approach can be used to identify co-integrating vectors among interest rate, fiscal deficit, public debt, inflation and international interest rate.

Now, to identify co-integrating vectors $(r)$ Johansen's approach suggested two likelihood ratio tests of significance, the Trace test and maximum Eigen value test.

$$
\begin{gathered}
\lambda_{\max }=-2 \ln (Q: r \mid r+1)=-T \ln \left(1-\lambda_{r+1}\right) \\
\lambda_{\text {trace }}=-2 \ln Q=-T_{i} \sum \ln \left(1-\lambda_{t}\right)
\end{gathered}
$$

In trace test, the Null hypothesis assumption is of ' $r$ ' co-integrating vectors against alternative of ' $n$ ' co-integrating vectors, which is greater than ' $r$ '. Monte Carlo Simulation and tabulation have been used to calculate the critical value (Johansen, 1988; Osterwald-Lenum, 1992).

Finally, it can be concluded that different steps were implicated in co-integration test. At first stage, order of stationarity of all variables has been determined. They must have same order of stationarity. In this analysis, it 
was found that all variables are stationary at first difference. Therefore, co-integration test was implemented to identify the determinants of interest rate. In second step, selection of optimal lag length took place. Optimal lag length depends upon Akaike information criterion (AIC) and Schwartz Bayesian criterion (SBC). After the selection of optimal lag length, next step concerns the identification of the number of co-integrating vectors.

\subsubsection{Error Correction Model}

After establishing the long-run relationship or equilibrium between variables, short-run disequilibrium may be assumed and error term involved in unit root test considered as equilibrium error. The Error Correction Mechanism (ECM) was for the first time introduced by Sagan and latter by Engle and Granger (1987) [23].

Johansen's long-run co-integrating methodology has been extended to Vector Error Correction Model (VECM) that helps to analyze time series more efficiently for which data is available only for short periods (Persaran et al., 2000 [24]). Error correction model is also termed as short-run model. If different variables exhibit long-run relationship between them, then short-run analysis or error correction process must also be carried out between them. This model adjusts the long-run equilibrium after a short-run shock (Engle and Granger, 1987, [23]).

\subsubsection{Granger Causality Analysis}

The Granger representation theorem generalizes that if two series $\mathrm{X}$ and $\mathrm{Y}$ are co-integrated then relation between two series can be presented as ECM. The most significant advantage of ECM is that it eliminates the problem of correlation between dependent and independent variables.

$$
\begin{gathered}
\Delta \mathrm{LINT}_{t}=\mu_{o}+\sum_{i=1}^{3} \mu_{1 i} \Delta \mathrm{LINT}_{t-i}+\sum_{i=1}^{3} \mu_{2 i} \Delta \text { LFDFCT }_{t-i}+\sum_{i=1}^{3} \mu_{3 i} \Delta \text { LGOVD }_{t-i} \\
+\sum_{i=1}^{3} \mu_{4 i} \Delta \mathrm{LINFL}_{t-i}+\sum_{i=1}^{3} \mu \Delta \text { LUSINT }_{t-i ?} \text { ? } \\
\left(\mathrm{LINT}_{t-i}-\beta_{1} \mathrm{LFDFCT}_{t-i}-\beta_{2} \text { LGOVD }_{t-i}-\beta_{3} \text { LINFL }_{t-i}-\beta_{4} \text { LUSINT }_{t-i}\right)
\end{gathered}
$$

\section{Empirical Results}

There are two parts in the analysis: unit root test and co-integration. All the results reported in the paper are conceded out by STATA (version. 10). Table 1 shows that the ADF-test statistic value in absolute term is smaller than critical value for all the variables included in the model. So the null hypothesis that data is non-stationary was accepted and it found that data is non-stationary at level form. Again the critical values were compared with the ADF-test statistic values after differencing the data first. The results showed that at first difference form, the critical values in absolute term are smaller than the ADF-test statistic values for all the data series. Thus it found out that all the variables are stationary at first difference form.

In Johansen's co-integration procedure, the first and foremost step is the selection of the order of VAR which is the primary step in the long-run analysis. For the selection of the order of VAR, adjusted LR test was carried out with maximum of four lags. It checked the adjusted LR probability value moving down to upward from 0 to 4. The order of VAR can be selected accordingly by finding the probability value of more than 0.05 which is greatest among all other values. So the order of VAR one was selected. After the selection of order of VAR, two likelihood Ratio (LR) tests were used in Johasen's co-integration approach and verified the existence of co-integrating vectors in the model. Maximum eigen value test and trace test results are shown in Table 2 which

\begin{tabular}{ccc}
\hline Table 1. ADF unit root results. & & \\
\hline Variables & Level & First Difference \\
\hline LINT & -3.066 & $-4.435^{*}$ \\
LFDFCT & -1.564 & $-4.182^{*}$ \\
LGOVD & -2.136 & $-4.307^{*}$ \\
LINFL & -3.286 & $-7.305^{*}$ \\
LUSINT & -3.207 & $-4.485^{*}$ \\
\hline
\end{tabular}

"reflects the significance at 1 percent critical value. Source: author's own calculations. 
proved the presence of co-integrating vectors in the model.

The results shown in the Table 3 can be written in the equation form as:

$$
\text { LINT }=-1.05+0.08 \text { LFDFCT + 0.33LGOVD + 0.38INFL + 0.56LUSINT }
$$

The results of above equation show that one percent increase in overall fiscal deficit attributed 0.08 percent increase in the interest rate in Pakistan. The sign of overall fiscal deficit as percent of GDP (FDFCT) is positive and significant. The total government debt as percent of GDP (GOVD) is significant at 95 percent level with positive sign having coefficient value of 0.33 . This implies that one percent increase in total government debt as percent of GDP is found to increase 0.33 percent in interest rate .One percent increase in rate of inflation caused 0.38 percent change in the interest rate. The interest rate and inflation has a significant and positive relationship at 95 percent level. The US interest rate, used as proxy for international interest rate, showed insignificant relationship. The coefficient value described a change of 5.58 percent in interest rate due to one percent increase in international interest rate change.

The results are also in line with the studies of Brzezina (2002) [15], Obi and Nurudeen (2009) [16], Laubauch (2003) [6], Gale and Peter (2003) [7], Qiang Dai and Thomas Phollipon (2004) [9], Kameda (2008) [10], BongaBonga (2011) [2], Shapiro (2004) [12], Gosselin and Lalonde (2005) [13] and Marattin and Salotti (2010).

\section{Vector Error Correction Model Results}

Error correction model is used for the short-run dynamics after the establishment of long-run relationship among variables (Table 4).

Table 2. Johansen co-integration rank tests.

\begin{tabular}{cccccc}
\hline \multicolumn{2}{c}{ Hypothesis } & \multicolumn{2}{c}{ Maximal Eigen Value Test } & \multicolumn{2}{c}{ Trace Test } \\
\hline Null & Alternative & Statistic & 95\% Critical Value & Statistic & 95\% Critical Value \\
\hline $\mathrm{r}=0$ & $\mathrm{r}=1$ & 36.8065 & 34.4000 & 78.9597 & 75.9800 \\
$\mathrm{r} \leq 1$ & $\mathrm{r}=2$ & 18.8899 & 28.2700 & 42.1532 & 53.4800 \\
$\mathrm{r} \leq 2$ & $\mathrm{r}=3$ & 13.4423 & 22.0400 & 23.1633 & 34.8700 \\
$\mathrm{r} \leq 3$ & $\mathrm{r}=4$ & 7.2909 & 15.8700 & 9.7210 & 20.1800 \\
\hline
\end{tabular}

Source: Author's calculations based on the data taken from GOP, 2011.

Table 3. Estimated Johansen’s normalized estimates.

\begin{tabular}{cc}
\hline Variables & Long-Run Elasticties \\
\hline LINT & $-1.00(1.00)$ \\
LFDFCT & $0.079(3.18)$ \\
LGOVD & $0.338(2.46)$ \\
LINFL & $0.376(3.69)$ \\
LUSINT & $0.559(0.63)$ \\
INTERCEPT & $-1.05(1.25)$ \\
\hline
\end{tabular}

Note: the values in brackets are the t-ratios. Source: Author's calculations based on the data taken from GOP, 2011.

Table 4. The error correction estimation for interest rate model.

\begin{tabular}{cc}
\hline Variables & Short-Run \\
\hline DLFDFCT $(-2)$ & $0.418(1.465)$ \\
DLGOVD (-2) & $0.123(1.500)$ \\
DLINFL (-2) & $0.173(2.845)$ \\
DLUSINT (-2) & $-0.078(1.22)$ \\
ECM1 & $-0.127(2.98)$ \\
$\mathrm{R}^{2}$ & 0.54 \\
\hline
\end{tabular}

Note: t-ratios are in parenthesis. Source: Author’s calculations. 
The short-run dynamics showed that only the inflation rate LINFL has a short-run impact on the interest rate LINT. It showed that one percent increase in inflation caused 0.17 percent increase in interest rate change in the short-run. The short-run impact of inflation on the interest rate was also justified by Adjei et al. (2012) [18] and Brzezina (2002) [15]. They showed that inflation and interest rate has short-run dynamics and any divergence from equilibrium caused by inflation has a significant short-run impact or disequilibrium in the interest rate. The ECM coefficient showed that the adjustment of short-run dynamics into the long-run equilibrium was 12 percent. It depicts that about 8 years are required to adjust the disequilibrium to the long-run equilibrium. The $\mathrm{R}^{2}$ value described that the model explained by the independent variables only 54 percent in the short-run.

\section{Summary, Conclusions and Policy Recommendations}

Interest rate is a fundamental element in the monetary policy implication. The pillars of the monetary policy are based on the interest rates. There are many determinants contributing in the interest rate fluctuations but the present study has focused on the four major determinates of interest rate change. These included the overall fiscal deficit, government debt to GDP ratio, inflation rate and international interest rate. The long-run impacts of these determinants were assessed on the interest rate change in Pakistan by employing the co-integration technique. All the variables were found to have positive and significant impact on interest rate change in Pakistan except the variable of international interest rate change. The international interest rate has no long-run effect on the domestic interest rate. The short-run error correction model depicted that adjustment speed of short-run dynamics to the long-run equilibrium was 12 percent. It means that about 8 years are required to adjust the disequilibrium to the long-run equilibrium.

The policy maker should devise certain policies to keep the interest rate low and control its fluctuations over the time. It is suggested that fiscal burden should be controlled by the government. The government should establish the structural reforms of taxes and expenditure systems in order to eliminate the fiscal deficits. The double digit inflation should also be controlled. The government should give attention to the Public Sector Development Programs (PSDP) in order to overcome the economic disabilities. The government should control her borrowing from the foreign institutions, and the efficient and effective foreign debt management should be implemented.

\section{References}

[1] Gigineishvili, N. (2011) Determinants of Interest Rate Pass-Through: Do Macroeconomic Conditions and Financial Market Structure Matter? IMF Working Paper No. 11, African Department, 176.

[2] Bonga-Bonga, L. (2011) Budget Deficit and Long-Term Interest Rates in South Africa. African Journal of Business Management, 6, 3954-3961.

[3] ADB (2004) Pakistan Economic Update (July 2003- June 2004). Asian Development Bank, Mandaluyong.

[4] Cohen, D. and Garnier, O. (1991) The Impact of Forecasts of Budget Deficits on Interest Rates in the United States and Other G-7 Countries, Federal Reserve Board.

[5] Canzoneri, M.B., Cumby, R.E. and Diba, B.T. (2002) Should the European Central Bank and the Federal Reserve Be Concerned about Fiscal Policy? Federal Reserve Bank of Kansas City, 333-389.

[6] Laubauch, T. (2003) New Evidence on the Interest Rate Effects of Budget Deficits and Debt. Board of Governors of the Federal Reserve System.

[7] Gale, W.G. and Orszag, P.R. (2003) Economic Effects of Sustained Budget Deficits. National Tax Journal, 56, 463485. http://dx.doi.org/10.17310/ntj.2003.3.02

[8] Bashir, R. (2004) Pakistan’s Fiscal Deficit.

[9] Dai, Q. and T. Philippon. (2004) Government Deficits and Interest Rates: A No-Arbitrage Structural VAR Approach. New York University, New York.

[10] Kameda, K. (2008) Budget Deficits, Government Debt and Interest Rates in Japan: An Analysis Using Published Budgetary Forecasts. Kwansei Gakuin University, Nishinomiya.

[11] Engen, E. and Hubbard, G. (2004) Federal Government Debt and Interest Rates. American Enterprise Institute, Working Paper No. 105, Washington DC.

[12] Shapiro, M.D. (2005) Federal Government Debt and Interest Rates. NBER Macroeconomics Annual, 19, 83-160.

[13] Gosselin, M.A. and Lalonde, R. (2005) MUSE: The Bank of Canada’s New Projection Model of United States Economy. Bank of Canada Technical Report No. 6. 
[14] Utami, S.T. and Inanga, E.L. (2009) Exchange Rates, Interest Rates, and Inflation Rates in Indonesia: The International Fisher Effect Theory. International Research Journal of Finance and Economics, 26, 151-169. http://www.eurojournals. com/finance.htm

[15] Brzezina, M.B. (2002) The Relationship between Real Interest Rates and Inflation. National Bank of Poland Working Papers 23, National Bank of Poland, Economic Institute.

[16] Obi, B. and Nurudeen, A. (2009) Does Fiscal Deficit Raise Interest Rates in Nigeria? A Vector Autoregression Approach. Journal of Applied Quantitative Methods, 4, 3.

[17] Hall, G.J and Sargent, T.J. (2010) Interest Rate Risk and Other Determinants of Post WWII. US Government Debt/ GDP Dynamics, October 26, 2010.

[18] Adjei, C.K.K., Mayer, R.W. and Chien, W.W. (2012) Determinants of Long-Term Interest Rate in the United States. Journal of Business \& Economics Research, 10, 5.

[19] Haq, A. and Aurangze, B. (2012) Determinants of Inflation in Pakistan. Universal Journal of Management and Social Sciences, 2, 4.

[20] Dickey, D.A., Bell, W.R. and Miller, R.B. (1986) Unit Root in Time Series Models: Tests Implications. The American Statistician, 44, 12-24.

[21] Hjalmarsson, E. and Osterholm, P. (2007) Testing for Co-Integration Using the Jhoansen Methodology When Variables are Near Integrated. Board of Governors of the Federal Reserve System. International Finance Discussion Papers Number 915, December 2007.

[22] Johansen, S. and Juselius, K. (1990) Maximum Likelihood Estimation and Inferences on Co-Integration with Application to the Demand for Money. Oxford Bulletin of Econometrics and Statistic, 52, 170-209.

[23] Engle, R.F. and Granger, C.W.J. (1987) Co-Integration and Error Correction: Representation, Estimation and Testing. Econometrica, 35, 251-276. http://dx.doi.org/10.2307/1913236

[24] Pesaran, M.H., Shin, Y. and Smith, R.J. (2000) Structural Analysis of Vector Error Correction Models with Endogenous I(1) Variables. Journal of Econometrics, 97, 293-343. http://dx.doi.org/10.1016/S0304-4076(99)00073-1 